\title{
Optimisasi Ketebalan Dinding Model Atap Menara Siger Pada Proses Injection Molding
}

\author{
Yanuar Burhanuddin, Suryadiwansa Harun, Lapri Aries Pukesa \\ Jurusan Teknik Mesin, Universitas Lampung, Bandar Lampung 35145 \\ Email: yanuar.burhanuddin@eng.unila.ac.id
}

\begin{abstract}
Abstrak
Produk berbahan baku plastik semakin banyak dijumpai, mulai dari peralatan rumah, komponen elektronik hingga otomotif. Hal ini dikarenakan beberapa kelebihan yang dimiliki oleh plastik seperti ringan dan tahan karat, lebih murah dibandingkan dengan produk logam atau kayu serta proses pengerjaannya relatif mudah. Proses pembentukan produk plastik yang palingg umum digunakan adalah injection molding. Penggunaan plastik yang semakin mendominasi penggunaan material menuntut suatu usaha untuk mengurangi waktu dan biaya produksi, salah satu caranya yaitu dengan memanfaatkan program simulasi sebelum dilaksanakan di lantai produksi. Dengan simulasi pemoderan dapat diketahui ketebalan optimal suatu produk, sehingga produk yang dihasilkan memiliki ketebalan seminimal mungkin dengan kualitas yang dapat diterima. Penelitian ini akan mensimulasikan variasi ketebalan dinding terhadap waktu pengisian, suhu aliran depan, waktu pendinginan, cacat garis dan udara terperangkap. Variasi ketebalan yang dipilih yaitu $1 \mathrm{~mm}, 1,5 \mathrm{~mm}, 2 \mathrm{~mm}, 2,5 \mathrm{~mm}, 3 \mathrm{~mm}, 3,5 \mathrm{~mm}$ dan $4 \mathrm{~mm}$. Dari hasil simulasi didapatkan kesimpulan bahwa ketebalan optimal model adalah sebesar $2 \mathrm{~mm}$, dimana pada ketebalan ini memiliki waktu pengisian 2,753 detik, suhu aliran depan $230,3^{\circ} \mathrm{C}$, dan waktu pendinginan 25,8 detik. Cetakan (mold) mulai dapat terisi cairan plastik secara penuh mulai pada ketebalan 2 mm. Semua variasi ketebalan mengalami cacat produk yang semakin meningkat seiring dengan bertambah ketebalan model.

Kata kunci: Plastic Injection molding, ketebalan dinding, waktu pengisian, suhu aliran depan, waktu pendinginan, cacat garis, udara terperangkap
\end{abstract}

\section{PENDAHULUAN}

Plastic Injection molding merupakan proses pembentukan yang umum digunakan untuk menghasilkan produk plastik secara massal dengan toleransi dimensi yang baik dengan produktivitas dan ketelitian tinggi tetapi dengan biaya yang relatif rendah. Pada proses injection molding, bahan baku plastik yang telah dicairkan oleh heater ditekan oleh injector mengalir masuk menuju sebuah cetakan (mold). Kemudian didinginkan beberapa saat agar plastik yang ada di cetakan membeku. Setelah plastik membeku dan keras, plastik tersebut dikeluarkan dari mold, sehingga diperolehlah produk plastik sesuai dengan dimensi geometri yang diinginkan [1]

Untuk dapat menghasilkan produk dengan harga murah dan berkualitas, industri plastik dituntut untuk selalu berinovasi. Salah satu upaya yang dilakukan untuk mendapatkan harga murah yaitu dengan membuat produk dengan ketebalan seminimal mungkin yang masih dapat dibuat dengan kualitas yang masih dapat diterima. Upaya tersebut juga diiringi dengan mempertimbangkan kemudahan plastik untuk dibentuk pada mesin injection molding.

Ketebalan dinding selalu diupayakan seoptimal mungkin. Dari beberapa literatur dikatakan bahwa ketebalan dinding dapat berkisar antara 0,5 mm - $4 \mathrm{~mm}$. Ketebalan yang dibuat tergantung pada desain produk, ukuran produk dan syarat fungsionalnya [2] .

Dalam proses injection molding terdapat fenomena short-shot area (bagian pada cavity yang tidak terisi melt) yang dapat menimbulkan cacat produk yang diakibatkan oleh tekanan injeksi yang kurang. sehingga perlu dilakukan penelitian variasi dinding yang optimal.
Sebelum diadakan pengujian secara riil, melalui simulasi proses injeksi pola aliran plastik didalam cetakan dapat dilihat. Penggunaan perangkat lunak untuk mensimulasikan proses produksi dapat menghemat biaya pengembangan produk karena tidak perlu melakukan percobaan secara riil [1].

Penelitian ini akan membuat desain model miniatur atap menara siger berbahan baku polypropylene. Model miniatur material plastik dalam proses injection molding dapat didesain dengan menggunakan perrangkat lunak. Model dibuat dengan bervariasi ketebalan mulai dari $1-2 \mathrm{~mm}$ dengan kenaikan 0,25 $\mathrm{mm}$. Model tersebut secara simulasi akan diuji kemampuan dari plastik cair untuk mengisi mold serta dilakukan analisa kualitas. Pengujian dilakukan menggunakan software Moldflow Plastic Advisers 7.3 (MPA 7.3). Saat simulasi, temperatur mold, temperatur melt dan tekanan injeksi dibuat konstan.

\section{METODA PENELITIAN}

\section{Pemodelan Atap Menara Siger}

Model miniatur atap Menara Siger mempunyai dimensi panjang $295 \mathrm{~mm}$, lebar $114 \mathrm{~mm}$ dan tinggi 132 mm. Bentuk model miniatur atap Menara Siger dapat dilihat pada Gambar 1. Untuk mempermudah analisis maka simulasi pemodelan dibuat simetri terhadap bidang xy. Dalam pelaksanaan simulasi model miniatur atap Menara Siger divariasikan ketebalan dindingnya. Variasi ketebalan dinding model yaitu $1 \mathrm{~mm} ; 1,5 \mathrm{~mm} ; 2 \mathrm{~mm} ; 2,5$ $\mathrm{mm} ; 3 \mathrm{~mm} ; 3,5 \mathrm{~mm}$ dan $4 \mathrm{~mm}$. 


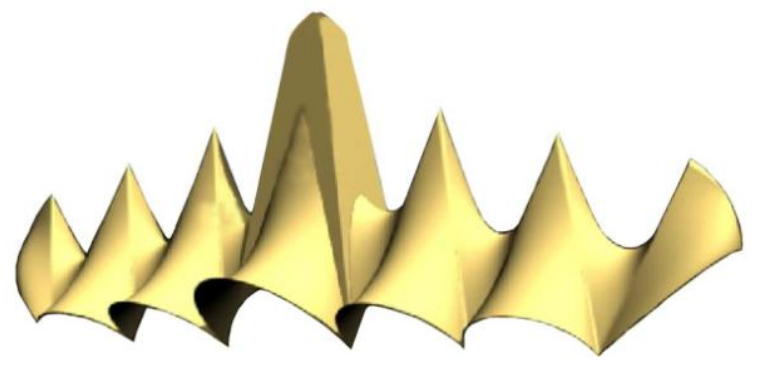

Gambar 1 Gambar model miniatur atap Menara Siger

\section{Material}

Material yang digunakan sebagai bahan baku model miniatur atap Menara Siger adalah polipropilen dengan nama komersial AP 6106HS. Karakteristik polipropilen dapat dilihat pada tabel 1 .

Tabel 1 Karakteristik Polipropilen [3]

\begin{tabular}{lll}
\hline Struktur & $:$ & Ko-polimer \\
\hline Suhu leleh $\left({ }^{\circ} \mathrm{C}\right)$ & & $210-290$ \\
\hline Kepadatan $\left(\mathrm{kgm}^{-3}\right)$ & $:$ & 905 \\
\hline Kekuatan tarik $(\mathrm{MPa})$ & $:$ & 25 \\
\hline Modulus kelenturan $(\mathrm{GPa})$ & $:$ & 1 \\
\hline Pemanjangan sampai patah $(\%)$ & $:$ & 300 \\
\hline Kekerasan & $:$ & $\mathrm{RC} 80$ \\
\hline Impak $\left(\mathrm{Izod}, \mathrm{kJm}^{-1}\right)$ & $:$ & 0,1 \\
\hline
\end{tabular}

\section{Kondisi Simulasi}

Kondisi operasi simulasi yaitu suhu mold $50^{\circ} \mathrm{C}$, suhu leleh polipropilen $250^{\circ} \mathrm{C}$ dan tekanan injeksi $120 \mathrm{MPa}$. Setelah ditetapkan material dan kondisi operasi maka simulasi dilakukan menggunakan Moldflow. Parameter hasil yang dilihat dari simulasi yaitu waktu pengisian, suhu aliran depan, waktu pendinginan, cacat garis dan udara terperangkap.

Sebelum melakukan simulasi terlebih dahulu dilakukan analisis lokasi gate yang optimal. Analisis lokasi gate bertujuan untuk memperoleh penempatan gate dengan prediksi kualitas yang baik sehingga meminimalisasi kemungkinan cacat pada produk. Hasil analisa lokasi gate terlihat seperti pada gambar 2. Dari gambar tersebut terlihat warna yang mengindikasikan bahwa lokasi gate paling baik ditandai dengan daerah y'ang berwarna biru, daerah yang baik ditandai dengan warna hijau, daerah yang kurang baik ditandai dengan warna kuning, sedangkan daerah yang buruk untuk dijadikan gate adarahdaerah yang ditandai dengan wama merah. Karena pada puncak tengah model Menara Siger terlihat berwarna hijau dan simetri maka lokasi tersebut dipilih sebagi gate.

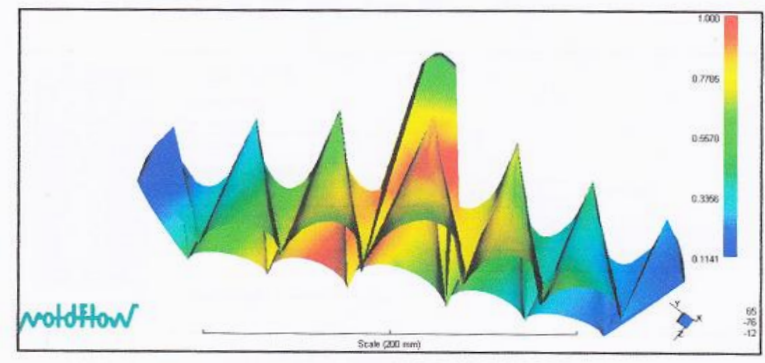

Gambar 2 Pemilihan lokasi saluran masuk (gate)

\section{HASIL DAN PEMBAHASAN}

Setelah dilakukan simulasi Moldflow 7 variasi ketebalan dinding atap miniatur menara siger maka diperoleh nilai waktu pengisian, suhu aliran depan, waktu pendingin serta imej cacat garis dan udara terperangkap dari. Data hasil dari simulasi Moldflow dapat dilihat pada tabel 2 .

Tabel 2 Data hasil simulasi

\begin{tabular}{ccccc}
\hline No & $\begin{array}{c}\text { Ketebalan } \\
(\mathrm{mm})\end{array}$ & $\begin{array}{c}\text { Waktu } \\
\text { Pengisian } \\
\text { (detik) }\end{array}$ & $\begin{array}{c}\text { Suhu } \\
\text { Aliran } \\
\text { Depan } \\
\left({ }^{\circ} \mathrm{C}\right)\end{array}$ & $\begin{array}{c}\text { Waktu } \\
\text { Pendingin- } \\
\text { an (detik) }\end{array}$ \\
\hline 1 & 1 & 1,388 & 230,5 & - \\
\hline 2 & 1,5 & 3,568 & 230,3 & - \\
\hline 3 & 2 & 2,753 & 230,3 & 25,8 \\
\hline 4 & 2,5 & 2,988 & 230,2 & 43,99 \\
\hline 5 & 3 & 3,113 & 230,1 & 60,7 \\
\hline 6 & 3,5 & 3,280 & 230,1 & 147,9 \\
\hline 7 & 4 & 3,855 & 230,1 & 102,9 \\
\hline
\end{tabular}

Kurva hubungan antara ketebalan produk dan parameter hasil dapat dilihat pada gambar 3, 4 dan 5. Pada gambar 3 terlihat bahwa waktu pengisian tertinggi terjadi pada ketebalan produk $4 \mathrm{~mm}$ dengan waktu pengisian 3,855 detik sedangkan waktu pengisian terendah terjadi pada ketebalan produk $1 \mathrm{~mm}$ yaitu 1,388 detik. Peningkatan waktu pengisian tertinggi terjadi antara ketebalan $1 \mathrm{~mm}$ dan $1,5 \mathrm{~mm}$ yaitu 2,18 detik. Hal ini dimungkinkan karena pada ketebalan $1,5 \mathrm{~mm}$ terjadi aliran balik fluida plastik cair yang disebabkan aliran turbulen pada model part yang belum dapat terisi penuh oleh plastik cair. Namun setelah ketebalan $2 \mathrm{~mm}$ hingga $4 \mathrm{~mm}$ waktu pengisian cenderung meningkat secara teratur. 


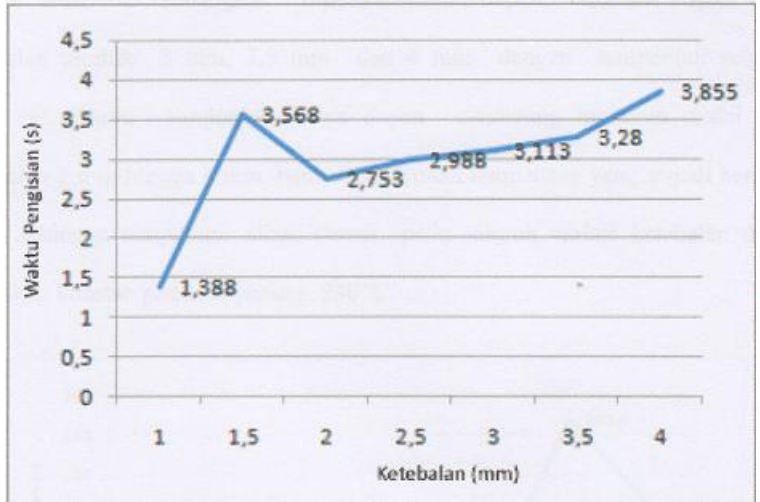

Gambar 3 Kurva waktu pengisian dari 7 variasi ketebalan produk

Untuk kurva suhu aliran depan pada gambar 4 terlihat bahwa suhu aliran depan menurun mulai pada ketebalan produk $1 \mathrm{~mm}$ dengan suhu $230,5^{\circ} \mathrm{C}$ sampai suhu aliran depan terendah yang terjadi pada ketebalan dinding 3 $\mathrm{mm}, 3,5 \mathrm{~mm}$ dan $4 \mathrm{~mm}$ dengan suhu $238,1{ }^{\circ} \mathrm{C}$.

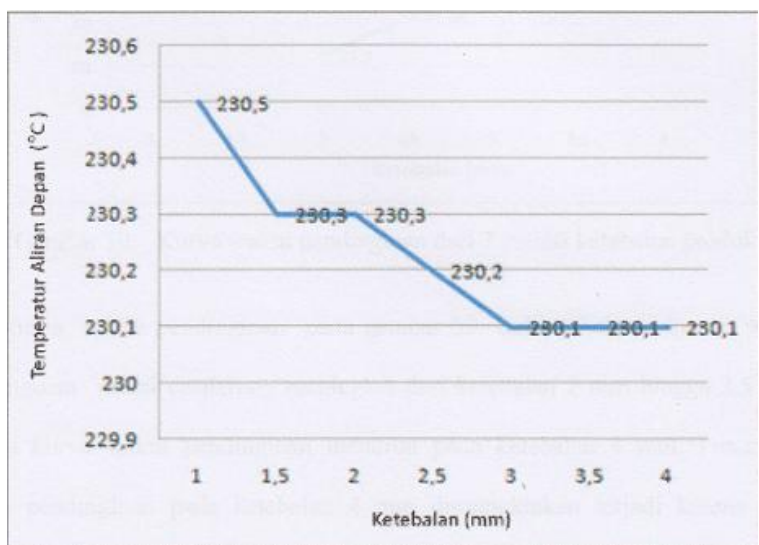

Gambar 4 Kurva suhu aliran depan dari 7 variasi ketebalan produk

Gambar 5 memperlihatkan kurva waktu pendinginan yang cenderung meningkat mulai ketebalan $2 \mathrm{~mm}$ hingga 3,5 mm, namun waktu pendinginan menurun pada ketebalan $4 \mathrm{~mm}$. Penurunan waktu pendinginan pada ketebalan $4 \mathrm{~mm}$ terjadi karena laju perpindahan panas berlangsung lebih cepat dari ketebalan sebelumnya. Pada ketebalan $1 \mathrm{rnm}$ dan 1,5 mm tidak dapat diketahui hasil analisa waktu

pendinginan, hal ini disebabkan karena pada kedua ketebalan tersebut produk belum dapat terisi dengan baik.

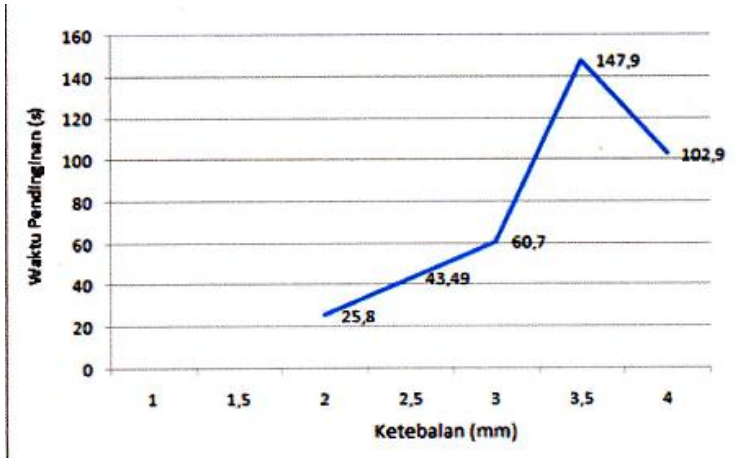

Gambar 5 Kurva waktu pendinginan pada berbagai variasi ketebalan

Analisis cacat produk berupa cacat garis dan udara terperangkap dalam simulasi ini menunjukkan seluruh variasi ketebalan model yang digunakan mengalami cacat produk. Namun cacat produk paling banyak terlihat pada ketebalan produk $4 \mathrm{~mm}$ (lihat gambar 6 dan 7) . Cacat produk paling sedikit terlihat pada ketebalan produk $1 \mathrm{~mm}$ (gambar 8 dan 9), namun pala ketebalan ini cairan plastik belum dapat mengisi secara penuh mold model. Dari perbandingan gambar hasil sirnulasi menunjukkan bahwa cacat produk meningkat jumlahnya seiring dengan bertambahnya ketebalan model.

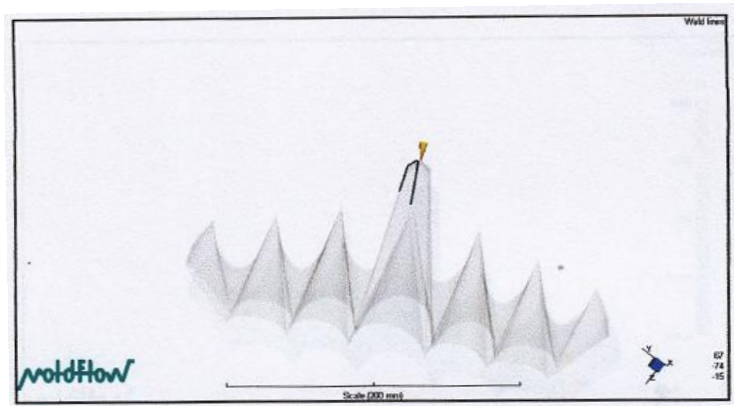

Gambar 6. Cacat garis yang terjadi pada ketebalan dinding $1 \mathrm{~mm}$

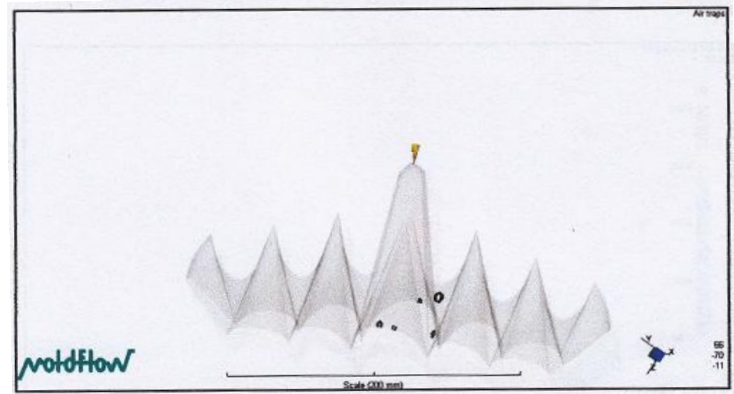

Gambar 7 Gas terperangkap pada dinding dengan ketebalan $1 \mathrm{~mm}$

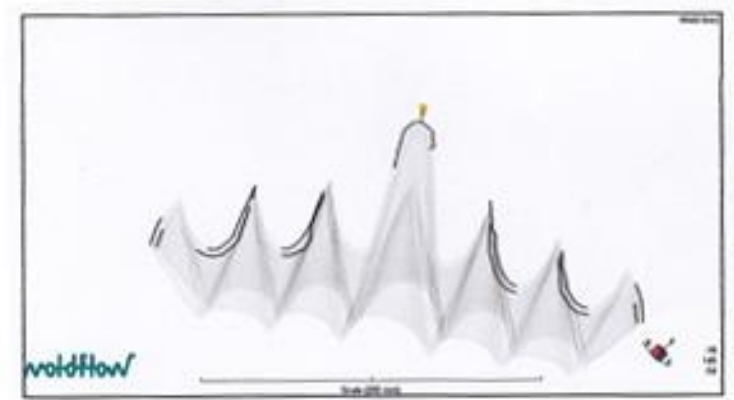

Gambar 8. Cacat garis terjadi pada ketebalan dinding 4 $\mathrm{mm}$ 


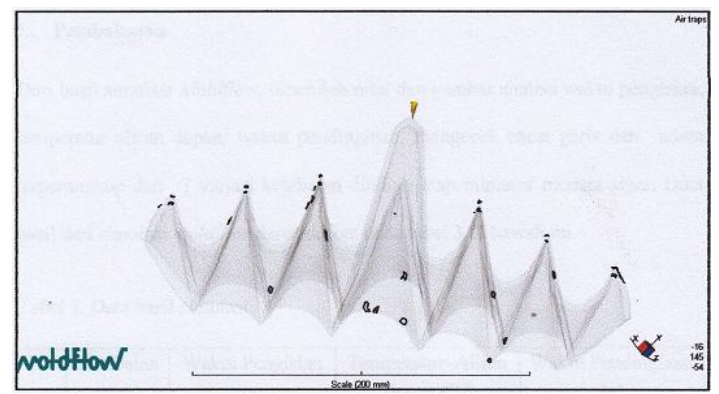

Gambar 9 Gas terperangkap terjadi pada ketebalan dinding $4 \mathrm{~mm}$

Dari analisis dapat disimpulkan bahwa pada ketebalan $1 \mathrm{~mm}$ dan 1,5 $\mathrm{mm}$ tidak dapat dipilih sebagai ketebalan optimal karena model miniatur belum dapat terisi penuh sehingga nilai waktu pendinginan tidak dapat diketahui seperti yang terlihat pada gambar 5, dengan dcmikian ketebalan optimal diperoleh adalah ketebalan $2 \mathrm{~mm}$. Hal ini berdasarkan pada fakta bahwa pada ketebalan $2 \mathrm{~mm}$ memiliki nilai waktu pengisian tercepat yaitu 2,753 detik dan waktu pendinginan tercepat yaitu 25,8 detik, sedangkan nilai suhu aliran depan relatif sama dengan ketebalan lainnya yaitu pada $230{ }^{\circ} \mathrm{C}$.

\section{KESIMPULAN}

Dari simulasi dan analisis variasi ketebalan dinding model miniatur dapat diambil beberapa kesimpulan:

1. Mold mulai dapat terisi cairan plastik secara penuh mulai ketebalan $2 \mathrm{~mm}$ sampai $4 \mathrm{~mm}$.

2. Dalam simulasi semua variasi ketebalan pada model miniatur mengalami cacat. Cacat produk meningkat seiring dengan ketebalan dinding.

3. Ketebalan optimal model adalah $2 \mathrm{~mm}$ dengan waktu pengisian tercepat 2,753 detik, suhu alitan depan 230 ${ }^{\circ} \mathrm{C}$ dan waktu pendinginan tercapat 25,8 detik. Pada ketebalan dinding $2 \mathrm{~mm}$ cacat garis dan udara terperangkap yang terjadi sedikit.

\section{DAFTAR PUSTAKA}

[1] K.A. Beiter \& K. Ishii D.R. Busick, "Design for injection molding: Using process simulation to asses tolerance feasibility," 1994.

[2] Amelia Sugondo, "Kajian Pengaruh Ketebalan Pada Kualitas dan Mampu Bentuk Dengan Menggunakan Simulasi Pada Proses Injection Molding (Studi Kasus: Model Gelas)," dalam Seminar Nasional Teknik Mesin 3 , Surabaya, 2008, pp. 1-5.

[3] Colin Hindle. Polypropylene. http://www.bpf.co.uk/plastipedia/polymers/pp.aspx. akses tanggal 11 November 2015 